\title{
Comparative Study to Amino Glycoside Antibiotics Resistance of Staphylococci Strains Isolated from Wounds at Brazzaville
}

\author{
Rachel Moyen ${ }^{1}$, Etienne Nguimbi ${ }^{2}$, Gabriel Ahombo $^{3}$, Nina Esther Ontsira ${ }^{4}$, Claudette Gatsele Yala ${ }^{5}$, \\ Obengui $^{6}$, Simon Charles Kobawila ${ }^{7}$, Delphin Louembe ${ }^{8}$
}

${ }^{1} \mathrm{Ph}$ D, Teacher-researcher, Laboratoire de biologie Cellulaire et Moléculaire Faculté des Sciences et Techniques, Université Marien NGOUABI

${ }^{2} \mathrm{Ph}$ D, Teacher-researcher, Laboratoire de biologie Cellulaire et Moléculaire Faculté des Sciences et Techniques, Université Marien NGOUABI

${ }^{3} \mathrm{Pph}$ D, Teacher-researcher, Laboratoire de biologie Cellulaire et Moléculaire Faculté des Sciences et Techniques, Université Marien NGOUABI

${ }^{4} \mathrm{Ph}$ D, Teacher-researcher, Laboratoire de Bactériologie et Virologie, Faculté des Sciences de la Santé Université Marien NGOUABI

${ }^{5} \mathrm{Ph} \mathrm{D}$, Teacher-researcher, Laboratoires de Biologie Médicale CBM- YALA

${ }^{6} \mathrm{Ph}$ D, Professor-researcher, Laboratoire de Bactériologie et Virologie, Faculté des Sciences de la Santé Université Marien NGOUABI

${ }^{7} \mathrm{Ph}$ D, Professor-researcher, Laboratoire de biologie Cellulaire et Moléculaire Faculté des Sciences et Techniques, Université Marien NGOUABI

${ }^{8} \mathrm{Ph}$ D, Professor-Researcher, Laboratoire de biologie Cellulaire et Moléculaire Faculté des Sciences et Techniques, Université Marien NGOUABI

\begin{abstract}
In order to improve the antibiotherapy and fight against the hospital infections, 52 Staphylococcus stains screened from the matter of patients have been tested for their sensitivity with seven antibiotics of the family of aminosids. The method of standard antibiogramm on Mueller Hinton medium was assayed. Isolation was made on Chapman agar. Identification has revealed 42 strains of Staphylococcus aureus and 10 coagulase-negative staphylococci. Resistance tests have shown the appearance of identical phenotypes in the two categories of staphylococci. However the resistance to aminosids is more important to the strains of Staphylococcus aureus.
\end{abstract}

Keywords: Staphylococci, résistance, amino-glycoside antibiotics, infections

\section{Introduction}

The bacteria of staphylococcus genus are presents in all environments. They are associated to the skin or to the mucous. In the hospital environment the staphylococcus are the most isolated bacteria. They are responsible of many infections $[4,7]$.

The widespread incidence of antibiotic resistance across various strains of $S$. aureus, or across different species of Staphylococcus has been attributed to horizontal gene transfer of genes encoding antibiotic/metal resistance and virulence. A recent study demonstrated the extent of horizontal gene transfer among Staphylococcus to be much greater than previously expected, and encompasses genes with functions beyond antibiotic resistance and virulence, and beyond genes residing within the mobile genetic elements [3]. The development of molecular typing methods has enabled the tracking of different strains of $S$. aureus. This may lead to better control of outbreak strains. A greater understanding of how the staphylococci evolve, especially due to the acquisition of mobile genetic elements encoding resistance and virulence genes is helping to identify new outbreak strains and may even prevent their
emergence[8].There are many antibiotics used in the treatments of staphylococci caused-infections. Among them are amino-glycoside. Although, nowadays selection of the antibiotics pressing, the lack of hygienic conditions and the growing number of sick people are among factors which enhance the growth and emergence of strains which are resistant to usual antibiotics. Whatever, the type of bacteria that resistance has become a word problem of public health [2]. In order to contribute to the improvement of the dealing and the fight against hospital infections, the present work is interested in the study of the staphylococci comparative resistance to aminoglycosids.

\section{Materiel and Methods}

\subsection{Strains isolation and used antibiotics}

Samples of matter from wounds of based-hospital sicks were collected and cultured in Chapman agar medium [4, 9, 13]. The genus staphylococcus, Gram positive bacteria were isolated and identified by using cultural and biochemical characters with Chapman media (production or not of yellow pigment). Identification was confirmed by the tests of catalase and coagulase. 


\section{International Journal of Science and Research (IJSR) \\ ISSN (Online): 2319-7064}

Index Copernicus Value (2013): 6.14 | Impact Factor (2014): 5.611

7 aminosids were used. : Streptomycin (S), kanamycin (K), Tobramycin (T), Gentamicin (GM), Amikacin (Ak), Néomycin $(\mathrm{Nm})$, Nétilmicin (Net).

\subsection{Strains susceptibility}

Strains were tested for their susceptibility to aminoglycoside by the standard method of antibiogramm, by disc diffusion on Mueller Hinton (Sanofi Pasteur), [1, 6, 9, 10]. Petri dishes were incubated at $37^{\circ} \mathrm{C}$ from 18 to 24 hours; diffusion diameter was measured and compared to the references diameter of the French society of microbiology [11-12]. The phenotypes of resistance have been determined with the results of antibiogramm by measuring the inhibition diameter.

\section{Results}

A total of 52 strains were isolated, among 42 of S.aureus $(80 \%)$ and 10 coagulase-negative Staphylococci CNS $(19 \%)$. Table I presents the results of the sensitivity and resistance tests of the staphylococci to amino-glycoside. In table I, the general resistance of staphylococci is about $68,70 \%$ and it is at $54,29 \%$ for CNS. The antibiotic family of amino-glycoside exhibits different activities in S.aureus strains and in the CNS strains.

In S.aureus strains, the resistance to kanamycin and tobramycin is high respetively $(97,60 \%)$ and $(80,96 \%)$. The rate resistance of streptomycin and neomycin are $66,66 \%$ and $64,28 \%$. The getamicin, the nétilmicin and the amikacin have been the most active aminosids with respectively $61,91 \%, 59,52 \%$ et $50,00 \%$.

For CNS, $30 \%$ of strains are resistant to amikacine and gentamicin. The netilmicin has been inactivated by $40 \%$ of the strains. Although, the activity is at the average for the neomycin and the tobramycin with $50 \%$ of resistances strains for each type. The less active (most inactive ) antibiotics are the streptomycin and the kanamycin with respectively 80 and $90 \%$ of resistant strains.

\section{Discussion}

Observed global resistance has been very high in the S.aureus strains. These results are opposed to those of Anne Decoster which emphases that CNS strains are more resistant than the $S$. aureus strain.

The rats resistance to amikacine, netilmicin and gentamin are comparable to those got by ar Dagnra and al.. [4].

The most involved describeb mecanism in 95\% of cases which explain the resistance to aminosids is the enzymatic inactivation by three groups of well known codified enzymes. [ 1,14].These enzymes are: The acetyltransférases (AAC), les nucleotidyltransferases), les phosphotransferases (APH).

Observed phenotypes are present in both Staphylococcus aureus strains and the coagulase négative staphylococci strains. Although, the predominance is observed in the $\mathrm{K}$ and the KT phenotypes of S.aureus strains. The KTGM phenotype revealed than the resistance to gentamicin can inactivate all the aminoglycoside and lead to endemic resistance; while the KT phenotype has arelation with the strains resistant to meticillin ( meti-R ); This phenotype appeared to $80 \%$ of S.aureus strains. The aminosids activities to staphylococci are indeed inhibited to Mety $-\mathrm{R}$ strains.

The apparition of the same phenotypes in the same genus can be explained by the crossed transmission of resistance genes by the phenomenon of conjugation [3].

\section{Conclusion}

The staphylococci resistance to aminods have become very important, $S$. aureus strains present a global resistance to aminosids which is very high comparing to the CNS. Although, the amikacin, the gentamicin, the nétilmicin and the neomycin can be used. . In order to improve antistaphlylococci treatments, these antibiotics have to be associated with glycopeptides or with fluoroquinolones.

\section{References}

[1] Bosgiraud Claudine, AEMIP (association des enseignants de microbiologie des facultés de pharmacie de France) 2003. Mécanismes de résistance. Microbiologie générale et santé; éd; ESKA, pp290-300

[2] Bouchaud O., S. Blanchy, Delmont j. F. Gay- Andrieu F. 2013. Resistance aux antibiotiques: un problème mondiale 2013 ; http //www.pathoexo.fr pp13

[3] Chan CX, Beiko RG, Ragan MA (2011). "Lateral transfer of genes and gene fragments in Staphylococcus extends beyond mobile elements". J Bacteriol 193 (15): 3964-3977.

[4] Dagnra A. Y., Hounkpati A., PRINCE -David M. 2001. Fort pourcentage de souches de Staphylococcus aureus résistant à la méticilline au CHU de Lomé Togo. Méd. Mal. Infect. 31(1):14 -17

[5] Decoster A. Les Staphylocoques ; FLM P :1-6

[6] Garret G., Cavallo J.D., Chardon H. et al 2001. Communiqué 2000- 2001 comité de l'antibiogramme de la société Française de microbiologie $47 \mathrm{p}$.

[7] Infection à Staphylocoques (2009), Med Qual Aout ; $P: 1-13$

[8] Lindsay J. 2008. Staphylococcus: Molecular Genetics. Caister Academic Press. ISBN 1-904455-29-8.

[9] Moyen R., Yala G. C., Obengui, Louembe D., Yala F. 2007.Résistance aux antibiotiques des staphylocoques isolés des foyers d'infections post-opératoires à Brazzaville.Annales de l'université Marien NGOUABI, Sciences de la Santé ; 8(5) :17-21

[10] Moyen Rachel, Ahombo Gabriel, Nguimbi Etienne et al. 2014 Activity of bêta lactamases in bacteria isolated from wounds infection in Brazzaville, Congo; AJMR 2290-2294

[11] Recommandations du Comité de l'antibiogramme de la société française de microbiologie édition janvier 2007; $49 \mathrm{p}$

[12] Recommandations du Comité de l'antibiogramme de la société française de microbiologie édition janvier $2012 ; 59 p$

\section{Volume 4 Issue 11, November 2015}




\section{International Journal of Science and Research (IJSR) \\ ISSN (Online): 2319-7064 \\ Index Copernicus Value (2013): 6.14 | Impact Factor (2014): 5.611}

[13] Tverdek FP. Crank CW, Sergreti J. 2008. Antibiotic therapy of methicillin- resistant Staphylococcus aureus in critical care; Crit Care Clin, 24(2): 249-60

[14]Udo EE, AL-Sweih N, Dhar R, Dimitoy TS, et al.2008.
Surveillance of antibacterial resistance in Staphylococcus aureus isolated in Kuwaiti hospitals. Med. Princ. Pract. 17 (1) : 71-75

Table 1: Activities of 7 aminosids to different types of staphylococci

\begin{tabular}{|c|c|c|c|c|}
\hline Tested ATB & $\mathrm{S}($ S. aureus) (\%) & $\mathrm{S}(\mathrm{CNS})(\%)$ & $\mathrm{R}($ S.aureus) (\%) & $\mathrm{R}(\mathrm{CNS})(\%)$ \\
\hline $\mathrm{K}$ & $1(2,40)$ & $1(10)$ & $41(97,60)$ & $9(90)$ \\
$\mathrm{T}$ & $8(19,04)$ & $4(40)$ & $34(80,96)$ & $6(60)$ \\
$\mathrm{GM}$ & $16(38,09)$ & $7(70)$ & $26(61,91)$ & $3(30)$ \\
$\mathrm{Ak}$ & $21(50,00)$ & $7(70)$ & $21(50,00)$ & $3(30)$ \\
Net & $17(40,48)$ & $6(60)$ & $25(59,52)$ & $4(40)$ \\
$\mathrm{S}$ & $14(33,34)$ & $2(20)$ & $28(66,66)$ & $6(60)$ \\
Nm & $15(35,72)$ & $5(50)$ & $27(64,28)$ & $5(50)$ \\
Total & $\mathbf{9 2}(\mathbf{3 1}, \mathbf{2 9})$ & $\mathbf{3 2}(\mathbf{4 5 , 7 1})$ & $\mathbf{2 0 2}(\mathbf{6 8 , 7 0})$ & $\mathbf{3 8}(\mathbf{5 4 , 2 9})$ \\
\hline
\end{tabular}

Legend: $\mathrm{S}=$ number of sensitive strains, $\mathrm{R}=$ number of resistant strains,

() are the percentage of sensitivity and resistance, $\mathrm{CNS}=$ coagulase- negative Staphylococci, $\mathrm{ATB}=$ Antibiotics

The following figure is showing the predominant resistant phenotypes observed in the study.

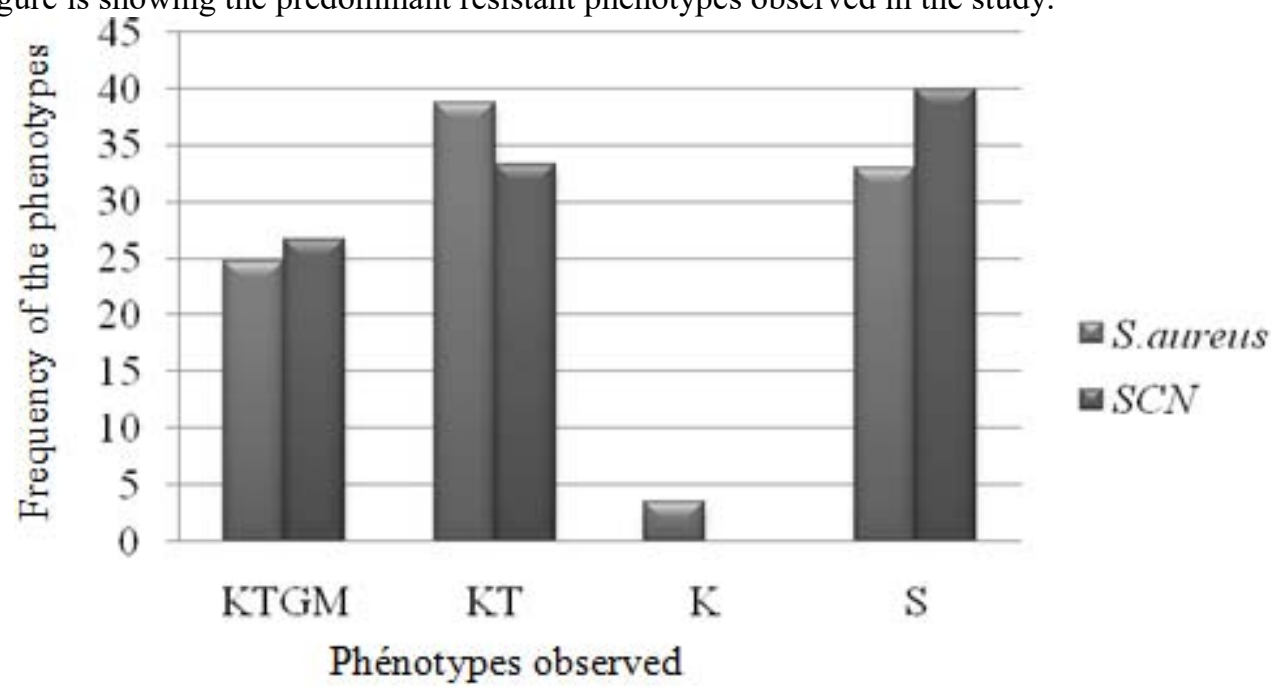

Figure 1 : resistant phenotypes of staphylococci to aminosids 